\title{
Ninfómanas, ciegas y mudas: enfermedad y escritura en la literatura de Margarita Aguirre, María Elena Gertner y Elisa Serrana*
}

Nymphomaniac, Blind and Mute: Disease and Writing in the Literature of Margarita Aguirre, María Elena Gertner, and Elisa Serrana

\author{
Andrea Kottow \\ Universidad Andrés Bello \\ akottow@unab.cl
}

La escritura de mujeres producida en Chile por las autoras adscritas a la así llamada Generación del 50 está colmada de tópicos de enfermedad. El presente trabajo explora la hipótesis de que estas imágenes patológicas responderían, a pesar de sus diagnósticos iniciales diversos, al modelo de la histeria, que hace confluir femineidad y enfermedad. En las obras Cuaderno de una muchacha muda de Aguirre, La mujer de sal de Gertner y En blanco y negro de Serrana, la escritura puesta en circulación propondría un juego de inflexiones e inversiones a partir de la imagen histérica, proveniente de una mirada masculina, sostén del poder patriarcal.

Palabras clave: Escritura de mujeres, enfermedad, histeria.

Writings by women produced in Chile as presented by authoresses belonging to the so-called generation of 1950, is filled with disease-related topics. The present paper explores the hypothesis that such images of pathology might fit the model of hysteria, in spite of a diversity of previous diagnoses, bringing femininity and disease to concur. In Aguirre's Cuaderno de una muchacha muda (Diary of a mute girl), Gertner's La mujer de sal (The woman of salt), and En blanco y negro (In white and black) by Serrana, writing proposes an interplay between inflections and inversions based on the image of hysteria resulting from a masculine view that sustains patriarchal power.

Keywords: Women's Writing, Disease, Hysteria.

Recibido $11 / 3 / 2013$

Aceptado 9/7/2013

* Este artículo fue desarrollado en el marco del Proyecto Fondecyt Regular No 1100754 "Tradición literaria y profesionalización en la escritura de mujeres chilenas", dirigido por Ana Traverso. 


\section{Palabras preliminares}

Los procesos de canonización en el campo literario son complejos y arbitrarios, respondiendo muchas veces a lógicas que se encuentran fuera de aquello que podría vehicular la mera calidad estética de una obra. Así lo demuestra paradigmáticamente la historia de la escritura de mujeres en Chile; son escasos los nombres que se recuerdan, pocos los estudios críticos que sobre escritoras mujeres se han realizado, siendo muchas de sus obras de difícil acceso por yacer olvidadas en alguna librería de viejos, sin haber sido reeditadas. Exceptuando los nombres de Gabriela Mistral, Marta Brunet y María Luisa Bombal -al pensar en la literatura escrita antes de los años ochenta del siglo XX, década en la que es posible situar una especie de "boom" de la literatura escrita por mujeres, y donde aparecen autoras de renombre internacional como Isabel Allende o Diamela Eltit- raras veces podremos encontrar a alguna autora integrando un programa de estudio o liderando las páginas de una historia literaria. Frente a este paisaje habrá que llegar a la conclusión de que la historia de la literatura chilena, sus hitos y textos nucleares son, en su abrumadora mayoría, masculinos. Y las mujeres que han llegado a ser aceptadas dentro de sus marcos, lo han hecho al precio de ser estereotipadas a partir de rasgos de género que exacerban su supuesta femineidad o terminan por negarla: madre universal una -Mistral-, viril y férrea otra -Marta Brunet-, señorita elegante y vulnerable la tercera -María Luisa Bombal- ${ }^{1}$.

Si bien en los últimos años es posible advertir un intento por revertir este panorama atravesado por gestos de exclusión respecto de la escritura de mujeres -lo que se traduce en proyectos de investigación dedicados a la producción literaria de mujeres y a publicaciones académicas que proponen nuevas lecturas sobre sus obras-, aún queda mucho terreno por explorar. Especialmente destacable es la gran cantidad de escritoras mujeres que publican dentro del paisaje nacional en las décadas del cincuenta y sesenta, en parte adscritas a la así llamada Generación del 50 -liderada por escritores tan ilustres como José Donoso, Jorge Edwards y Enrique Lafourcade-, en torno a la cual también se movieron las escritoras que serán estudiadas en el presente texto y cuya producción literaria es ampliamente desconocida. En 1954, con la publicación de su Antología del nuevo cuento chileno, Lafourcade sienta las bases del corpus de escritores que conformarán la generación del cincuenta. De las cinco mujeres consideradas por él en esta primera edición de su antología (María Elena Gertner, Yolanda Gutiérrez, Pilar Larraín, Gloria Montaldo, Margarita Aguirre y María Eugenia Sanhueza), en la versión que Lafourcade reedita en el año 1959 solo sobreviven dos: Margarita Aguirre y María Elena Gertner (Olea 102-3). Estos mismos dos nombres integran en tanto únicas mujeres la recolección de material crítico de prensa que congrega Eduardo Godoy en Generación del 50 en Chile, proponiéndose su

\footnotetext{
1 Para una discusión detallada de las imágenes genéricas que la crítica elaboró en torno a las figuras de Brunet y Bombal, véase Rubí Carreño, Leche amarga: violencia y erotismo en la narrativa chilena del siglo $X X$. Carreño evidencia en su análisis que no siempre estas imágenes sexuadas, en el sentido de responder a modelos genéricos dominantes, se mantienen idénticas a sí mismas en el tiempo, sino se muestran flexibles y van respondiendo estratégicamente a las maneras en que las mujeres las van deconstruyendo.
} 
antología como un "verdadero rescate cultural" (9). Godoy declara adoptar la denominación de la generación del cincuenta precisamente de Lafourcade, enriqueciéndola con una "conceptualización teórica" (13) basada en la noción generacional de Cedomil Goic, quien, a su vez, se afilia al criterio generacional histórico de Ortega y Gasset. Sin querer entrar en estos momentos a discutir las debilidades que el modelo generacional pudiese tener para el estudio de la literatura, quisiera destacar que el tipo de cofradía que privilegia pareciera más propicio para las fraternidades acaecidas entre grupos de hombres, especialmente en momentos históricos en las que las mujeres solían estar confinadas a la vida familiar y hogareña, siendo su participación en la vida literaria pública más bien reducida ${ }^{2}$. El menguado número de mujeres que pueblan los estudios basados en el modelo generacional contrasta, sin embargo, con lo que Lina Vera Lamperein denomina en su recopilación de las autoras mujeres en Chile "eclosión de la literatura femenina", y donde puede encontrarse el número no menor de 67 escritoras adscritas a las décadas del cuarenta, cincuenta y sesenta, según los años de sus publicaciones, y en las cuales aparecen respectivamente María Elena Gertner, Margarita Aguirre y Elisa Serrana. Son estos treinta años, entonces, que Lamperein considera un momento de especial fecundidad para la escritura de mujeres, proliferación que no se refleja en las historias de la literatura chilena, en la crítica académica ni en el panorama editorial. Raquel Olea, una de las pocas estudiosas que se han dedicado a la lectura y análisis de las escritoras que nos ocupan, destaca el surgimiento de una nueva generación, la que agrupa a las escritoras mujeres tanto incluidas en, como excluidas de, la generación del cincuenta "oficial", titulada compensatoriamente "Escritoras de la Generación del 50" (103). Sin embargo, este agrupamiento crítico no solo evidencia un intento de reclamar un lugar históricamente negado a las mujeres en tanto autoras, sino asimismo esta "generación inventada" (102) puede leerse como una invitación a revisitar una serie de textos, en pos de proponer nuevos accesos a ellos, invisibilizados por las lecturas canónicas, y que "legítimamente lea lo que de manera crítica no pudo considerarse" por los "signos de una cultura masculina" (104).

Quisiera trazar a continuación una aproximación a tres obras escritas en los años cincuenta y sesenta en Chile que, si bien son de autoría de las escritoras más afianzadas dentro del panorama que hemos esbozado más arriba, siguen habiendo recibido una escuálida atención crítica. Los tres textos -Cuaderno de una muchacha muda de Margarita Aguirre (1951), La mujer de sal de María Elena Gertner (1962) y En blanco y negro de Elisa Serrana (1968) - activan la metáfora de la enfermedad para problematizar las formas en que el discurso patriarcal ha significado la femineidad. En un

2 Si bien se ha demostrado que también las mujeres han sido inventivas en crear agrupaciones femeninas en torno a temas literarios (Vicuña, Doll), la intelectualidad generada en torno a los salones muestra diferencias sustantivas con la gestación y el sentido de pertenencia a una generación. Mientras que el salón es un espacio social, donde la mujer no amenaza con abandonar el rol tradicionalmente femenino, y las mujeres se dedican a leer y comentar en gran medida obras de escritores hombres admirados, la cofradía generacional presupone una conciencia autorial, la comparecencia de temas y preocupaciones compartidos y debatidos en un circuito colectivo así como la posibilidad de hacer circular estas problemáticas a través de publicaciones, 
diálogo tensionado por argumentos situados simbólicamente en lo masculino, estos textos procuran una visión que, sin abandonar los elementos constituyentes del discurso dominante, los reorganiza, ofreciendo posibilidades de su resignificación. La enfermedad toma en los tres casos formas aparentemente diversas; mientras que la protagonista de Aguirre es, como indica el título de la pequeña nouvelle, una muchacha muda recluida en un asilo para enfermos, el personaje de Serrana es una mujer ciega, que va relatando su vida en el campo chileno. Gertner constituye en La mujer de sal un personaje tachado de ninfómana por su amigo e interlocutor, simultáneamente receptor del texto que ella escribe. Lo que argüiré en el presente trabajo es que a pesar de las superficies disímiles de los cuadros patológicos convocados en estas narraciones, en los tres casos no se trataría sino de máscaras histéricas adoptadas por las mujeres en pos de desestabilizar el discurso masculinista. Mudez, ceguera y ninfomanía resultarían, entonces, imágenes vacuas, que más que generar identidades fijas escabullen a la estabilidad normativa de posiciones de género instituidas en un sistema patriarcal, para hacer circular lugares alternativos para lo femenino. En tanto cifra paradigmática de femineidad, la histeria sirve a los proyectos escriturales de Aguirre, Gertner y Serrana para develar cómo la histerización respondería a una reacción de lo masculino frente a las amenazas situadas en las mujeres, estrategia que sufre una inflexión al ser ocupada por las mismas autoras en su escritura. Analizaré entonces las imágenes patológicas puestas en juego en los tres textos para ir mostrando cómo sirven de plataforma móvil que vehiculiza formas excéntricas de habitar el género femenino, revelando un malestar y una inconformidad con los modos en que el sistema patriarcal ha imaginado $y$ estereotipado a lo femenino. En una mirada exploratoria me detendré, hacia finales del trabajo, en la puesta en escena de la problemática de la escritura que Cuaderno de una muchacha muda, La mujer de sal y En blanco y negro despliegan: los tres textos están escritos por mujeres que narran en primera persona, integrando una mirada metarreflexiva sobre su quehacer escritural. La imagen de la mujer escritora que escribe sobre la mujer escritora, a manera de la figura de las muñecas rusas, nos pone frente a un espejo infinito, momento abismal que vincularé con el tópico de la enfermedad. La escritura como enfermedad, pero también como única posibilidad de terapia y sanación, se plantea como topo recurrente en las autoras que escriben en este tiempo, problemática que se pondrá en relación con la autoría en tanto forma tradicionalmente masculina de asumir la paternidad sobre la propia obra (Gilbert \& Gubar).

\section{Máscaras histéricas: pliegues y reversos}

\subsection{Ninfomanía $y$ sinsentido femenino}

"Usted es una ninfómana": así el diagnóstico que Théo aventura con relación a su amiga Amalia, protagonista de La mujer de sal. Tan solo en la tercera página del texto e inmerso en su primer diálogo -sostenido entre las dos figuras principales- aparece este término, arrastrando consigo toda su carga patológica y estigma social. Luego Théo, algo atemorizado de haber molestado a Amalia con su veredicto, le pregunta: "¿Le asusta la palabra?". Lacónica es la respuesta de Amalia, cuando contesta: "No, no me asusta. Ya la había oído. Desgraciadamente no me aclara nada" (Gertner 13). 
Lo que Amalia pareciera aducir con su réplica es que el dictamen de Théo no sería más que el señalamiento de sus síntomas, con los que ya se encuentra familiarizada. En este sentido, no le da miedo la palabra por no decirle nada nuevo ni ominoso, y lo que lamenta es que el significante "ninfómana" no se adentre en las posibles causas de su sintomatología: no represente para ella un significado. Si aquello que se despliega con la palabra ninfomanía es su valor ilocutivo -aquello que la palabra realiza al ser pronunciada- más que aprehender la referencia a algo que estaría efectivamente "detrás" del significante, habrá que preguntarse qué es lo que pone en escena la ninfomanía.

La palabra ninfomanía ${ }^{3}$, que fusiona a las ninfas con la manía, es un neologismo inventado por la psiquiatría francesa del siglo XVIII, medicalizándose el término al alero de la posición privilegiada que adquiere la medicina en la modernidad. La ninfomanía es pensada entonces como una enfermedad exclusivamente femenina, que denuncia la hipersexualidad de la mujer, su incapacidad de interesarse o concentrarse en asuntos que escapen a las esferas de sexualidad y genitalidad. El correspondiente masculino sería la satiriasis o el donjuanismo, que indican la incansable necesidad de buscar en y a través del sexo, así como en el continuo cambio de la pareja sexual, una satisfacción inalcanzable. Lo que en el hombre, sin embargo, puede adquirir una dimensión existencial, como demuestran las distintas variantes del Don Juan en la tradición letrada ${ }^{4}$, aparece, en primera instancia, negada a la variante femenina. La mujer ninfómana no es, según las imágenes culturales dominantes en la tradición occidental moderna, aquella que busca a través del encuentro sexual ni el eterno masculino ni una verdad trascendente, sino, más bien, la que exacerba su naturaleza femenina. La ninfomanía representaría a la mujer en su esencia: ninfomanía y femineidad se superponen hasta hacerse indistinguibles, al igual que histeria y útero -hysteros- muestran confluencia etimológica.

Slavoj Žižek, al retomar en Las metástasis del goce la argumentación ofrecida por Otto Weininger en Sexo y carácter (1903), subraya la intención del vienés de negarle el estatuto de sujeto a la mujer. Para Weininger, la diferencia sexual reside precisamente en que el hombre es alguien, mientras que la mujer no tiene capacidades de constituir una existencia. La consecuencia final que se revela para Weininger, tras diferenciar los dos principios " $m$ " (masculino) $y$ "w" (femenino), es: "Las mujeres no tienen existencia ni esencia, no son,

3 Etimológicamente la palabra nos remite a la locura de las ninfas, deidades femeninas de carácter menor que en la mitología griega anima la naturaleza, atrayendo con su canto y promesas sexuales a los campesinos que pasan por el bosque, extraviándolos para que jamás vuelvan a sus hogares.

4 Peter Brooks rastrea diversas plasmaciones del Don Juan en la tradición cultural occidental para destacar que tanto en la versión de Molière del siglo XVII, en el Don Giovanni de Mozart, en las Memorias de Casanova y en variantes posteriores como el Diario de un seductor de Kierkegaard, Don Juan no busca en sus conquistas simplemente la satisfacción de su deseo sexual, sino expresaría un anhelo por una maestría cuya esencia estaría dada por el deseo de saber (11). Brooks cataloga esta línea de lectura como la tradición metafísica de Don Juan, que vincula de forma indisoluble la necesidad de seducir con una continua insatisfacción en la búsqueda de conocimiento (97). 
son nada. Se es alguien o nadie, según se sea hombre o mujer" (383)5. La negación de un yo inteligible, entendido en términos neokantianos, es, en el pensamiento de Weininger, resultado de la hipersexualidad de la mujer. Esta estaría presa de su cuerpo, de sus sensaciones y necesidades, siendo incapaz de cualquier profundidad espiritual. El sentido es privativo de la experiencia masculina; la mujer no busca sentido ni lo posee en tanto ser: es un ser sin sentido, un sinsentido. Histeria y femineidad son, en la perspectiva de Sexo y carácter, una y la misma cosa: la mujer se agota en su sintomatología corporal, detrás de ella no se encuentra nada. Es pura superficie, sin fondo. La mujer, entonces, es ninfómana por ser de sexo femenino; es histérica por ser mujer. Esta superposición de histeria y femineidad ha sido destacada por una serie de estudios que desde perspectivas culturalistas se han dedicado al análisis de la histeria ${ }^{6}$. Mujer-cuerpo-histeria: esta es la tríada que se muestra ante la mirada masculina y que, además, reclama su lectura. La falta de profundidad, el agotamiento en ser puro cuerpo histérico trae consecuentemente consigo la necesidad de posicionar al hombre como aquel que es capaz de dar cuenta de lo que la mujer solo involuntariamente exhibe. Janet Beizer postula en su estudio sobre las narrativas de la histeria en la Francia decimonónica: "En el cuerpo hiperfemenino, hiperexpresivo de la histérica, sexo y texto se reúnen" (22) ${ }^{7}$. Este texto, encarnado -literalmente- por la mujer, es descifrado por el hombre. El cuerpo, que es sexo, se vuelve texto, que requiere de la decodificación masculina. La posible inteligibilidad del texto histérico que exhibe el cuerpo enfermo de la mujer se extingue una vez que aparece el lector-traductor masculino.

"De hecho, el cuerpo no habla; es hablado, es convertido en ventrílocuo por un texto maestro que lo hace significar. La mujer se vuelve texto, pero es un texto dentro de otro texto, un texto enmarcado como fuente significante por medio de otro texto mediador" (Beizer 26) ${ }^{8}$. Es, entonces, un texto cuyo

\footnotetext{
5 "Die Frauen haben keine Existenz und keine Essenz, sie sind nicht, sie sind nichts, Man ist Mann oder man ist Weib, je nachdem ob man wer ist oder nicht". La traducción es mía. 6 Foucault reconoce en la "histerización del cuerpo de la mujer" uno de los grandes dispositivos de saber y poder que se despliegan a partir del siglo XVIII respecto del sexo, definiéndola como el "triple proceso según el cual el cuerpo de la mujer fue analizadocalificado y descalificado -como cuerpo integralmente saturado de sexualidad; según el cual ese cuerpo fue integrado, bajo el efecto de una patología que le sería intrínseca, al campo de las prácticas médicas..." (127), Georges Didi-Huberman propone en su Invención de la histeria a la Salpêtrière en tanto el espacio de una femineidad, cifrada en lo patológica, denominado el hospicio más grande de París, como "la ciudad de las mujeres incurables" (23). Janet Beizer define la histeria en tanto "figure of femininity, label of disorder and difference" (8), añadiendo que "hysteria and women have overlapping attributes (the 'characteristics' of hysteria are often borrowed from commonplaces about female nature so that the disease 'behaves' like a woman) is one more indication of the metaphoric nature of the diagnosis" (17), Peter Melville Logan reconoce un renovado interés del ámbito académico en los discursos sobre la histeria, señalando que la definición predominante de histeria puesta en juego en la crítica literaria proviene de la teoría psicoanalítica, por lo cualla "[h]ysteria is associated with woman's exclusion from the sphere of representation, the symbolic that is necessarily gendered male" (9),

7 "In the hysteric's hyperfemale, hyperexpressive body, sex and text are joined". La traducción es mía,

8 "In fact the body does not speak; it is spoken, ventriloquized by the master text that makes it signify. The woman becomes a text, but she is a text within a text, a text framed as signifying source by another, mediating text". La traducción es mía,
} 
sentido le es conferido por otro. Por ello es Théo quien diagnostica a Amalia en La mujer de sal, del mismo modo en que es Charcot quien teatraliza a sus histéricas en la Salpetrière y es Freud quien constituye los relatos clínicos de sus pacientes (mujeres): los tres se constituyen en lectores del cuerpo femenino exhibido a partir de sus signos histéricos, que serían mero espectáculo carente de sentido sin sus decodificadores y constructores de sustancia.

El epíteto de ninfómana utilizado en la novela de María Elena Gertner pareciera poner en circulación, precisamente, la argumentación de Otto Weininger, revisitada por Žižek: lo que Théo le dice a Amalia es que su enfermedad reside en ser mujer. Está condenada a agotarse en su sexualidad, porque detrás de ella no habría nada. Y es por esto mismo que Amalia formula la respuesta que da: el ser diagnosticada como ninfómana no le aclara nada, pues ofrece una explicación tautológica; si ninfomanía y femineidad son sinónimos, no puede curarse de su enfermedad.

En su ya clásico estudio sobre la escritura de mujeres La loca del desván, Gilbert y Gubar destacan la frecuente aparición de imágenes y metáforas de lo enfermo en la literatura producida por mujeres. Centradas en reflexionar acerca de la tradición anglosajona decimonónica, las autoras plantean que a falta de un canon en el cual inscribirse y del cual nutrirse, las escritoras trabajan con el material constituido por una cultura masculinista y por sus pares hombres. Enfrentadas a un cúmulo de imaginería que vincula femineidad y enfermedad, las autoras adoptarían en sus escritos los íconos patológicos, re- y sobreescribiéndolos: "Rodeada como está, por imágenes de enfermedad, tradiciones de enfermedad e invitaciones tanto a enfermar como a renunciar, no es sorprendente que la mujer escritora ha enfrentado la incomodidad respecto a su propia naturaleza con múltiples espejos" (57) ${ }^{9}$. Expresión, entonces, de una práctica que no guarda lugar para la mujer, el de la escritura, y de una incomodidad de habitar estas coordenadas culturales de la producción literaria, siendo a su vez evidencia de un malestar de encarnar un género que ha sido definido por el hombre, la enfermedad se vuelve cifra de una doble anomalía: ser escritora y mujer. Al trabajar con y sobre la metáfora de lo patológico, la escritura de mujeres se enfrenta con las imágenes que la cultura masculina ha constituido acerca de lo femenino. Así, en el caso de La mujer de sal de Gertner, la novela retoma con el diagnóstico de la ninfomanía, hecha por Théo, la condena de lo femenino a lo histérico.

\subsection{Ceguera y diferencia mutable}

Gilbert y Gubar destacan una serie de imágenes patológicas recurrentes en la escritura de autoras del siglo XIX en el ámbito anglosajón, que puede ser equiparado, en cierto sentido, con el panorama de la escritura de mujeres en Chile en el siglo XX. Mientras que el siglo XIX en Inglaterra y EE.UU. se convierte en el escenario del comienzo genealógico de la tradición escritural femenina -con autoras como Jane Austen, Emilie Dickinson o las hermanas

9 "Surrounded as she is by images of disease, traditions of disease, and invitations both to disease en to dis-ease, it is no wonder that the woman writer has held many mirrors up to the discomfort of her own nature". La traducción es mía. 
Brontë- recién en el siglo XX puede observarse un fenómeno comparable en Chile. Ana Traverso acentúa "la incipiente producción literaria de autoras mujeres, en el cambio del siglo XIX al XX" (61), arguyendo que Iris -Inés Echeverría- fuera "probablemente la primera escritora reconocida y autorizada como tal en Chile" (68), comenzando a publicarse su obra en 1910. Como he destacado en otro lugar ${ }^{10}$, las primeras escritoras en Chile coinciden en parte importante con las primeras feministas y su escenario de acción es la primera mitad del siglo XX. Por lo tanto, no parece arriesgado trasponer temporalmente lo que Gilbert y Gubar postulan respecto de la imaginería de la escritura de mujeres en el siglo XIX anglosajón a las obras de mediados del siglo XX en Chile. Las autoras de La loca del desván relacionan, como he recapitulado más atrás, las enfermedades que pueblan las obras de las escritoras estudiadas con el problema de la autoría y el género. Una sintomatología que parece especialmente apta para articular este nudo temático entre escritura y femineidad es el de la ceguera. La imposibilidad de ver funcionaría, así el planteamiento que quisiera hacer, como una especie de metáfora no solo de las dificultades que tiene la mujer de ver, es decir, de entender un sistema social constituido y liderado por una cultura patriarcal, sino también en tanto espejo inverso de las formas en que ellas son (no) vistas por esa cultura masculina. Los hombres y la cultura que lideran, serían, en este sentido, los ciegos, convirtiendo a la mujer en un resto de difícil administración que para su domesticación es rotulado de enfermo.

Elisa Serrana convierte a una ciega en la protagonista de su novela En blanco y negro, publicada en 1968, recurriendo, asimismo, al expediente de la primera persona. Relata la experiencia de una joven ciega, desde su infancia hasta la primera adultez. Libertada del trato que reciben los demás niños, la ciega crece compartiendo los hábitos de los animales, echada en el suelo, sintiendo la materialidad de las cosas antes de captarla discursivamente. La ceguera se vuelve sinónimo de su incapacidad para el raciocinio, lo que, a su vez, la destituye del estatuto de sujeto. Su manera de aprehender el mundo por medio de los sentidos la iguala a las bestias, alejándola de la humanidad. Tachada en repetidas ocasiones de "tonta" y "estúpida", se le dispensa de ir a la escuela, y acceder a educación y cultura. Las únicas alianzas que logra hacer en la casa familiar situada en el campo chileno, donde confluyen abuelos, tíos, tías, padres y primos, cuyas relaciones familiares se han visto trizadas por abandonos y muertes, son las que establece con tía Clara, una solterona con inclinaciones místicas, y con su primo José Luis, que termina decidiéndose por el seminario con fines de hacerse cura. Tanto Clara como José Luis peligran constantemente con ser despojados de la consideración íntegra de sujetos racionales; Clara tiene fama de loca, y José Luis cae en desgracia, sobre todo en ojos de su padre, cuando pretende renunciar a la terrenidad para consagrar su vida a Dios. Situados en un límite hacia la excentricidad radical, que los convierte en personas cuya racionalidad a su vez se percibe como débil y permeable, entran en serie con la ciega, cuya no videncia se vuelve cifra de su falta de humanidad. El padre de José Luis construye una galería con los tres personajes, en la que el denominador común es este

10 Andrea Kottow, "Feminismo y femineidad: escritura y género en las primeras escritoras feministas en Chile", Aceptado para su publicación en Atenea, 
carácter híbrido que los marca como seres sin género, como sujetos en el límite de su inteligibilidad. Con relación a su hijo grita: "Veremos si se atreve a irse con los frailes... Hay que tener cojones para hacerlo y él no los tiene" (212). Y respecto de su hermana Clara y la sobrina ciega declama: "Miren qué suertecita la mía, vivir solo con dos mujeres. Es decir, dos semimujeres, una loca y otra ciega, y no es esto lo más importante: las dos parientas. iPor la madre!..." (220). A su hijo José Luis le arranca simbólicamente los testículos, cuestionando con ello no solo su masculinidad, sino, finalmente, su calidad de sujeto íntegro y válido, así como disputa la femineidad de su hermana Clara y de su sobrina ciega, al tratarlas de semimujeres, es decir, de mujeres que no lo serían del todo, pero no porque su género se rebase hacia lo masculino, sino porque no son sujetos que puedan ser considerados como tales de manera absoluta.

Tanto la exacerbación de la femineidad como su escamoteo entran en relación con la histeria. Como plantea Beizer: "...la categoría diagnóstica se había convertido, de hecho, en un vehículo para la imaginación" (17) ${ }^{11}$. Esta imaginación tiende al vaciamiento de la categoría de lo femenino, sea por su hiperbolización o por la negación a cumplir el supuesto modelo idóneo de mujer. "La histeria, ostensiblemente un punto de demarcación genérica, resulta ser un punto de inflexión en el cual las categorías dicotómicas, constitutivas del diagnóstico (femenino/masculino, cuerpo/mente, fragmentación/cohesión), ya no se sostienen" $(11)^{12}$. Loca y ciega se vuelven síntomas a partir del cual sustraerle la posibilidad de habitar en plenitud el género femenino, y donde al mismo tiempo se estrellan las categorías y clasificaciones genéricas.

Pero no solo las palabras del tío, representante de una masculinidad tradicional, burda y violenta, cuestionan la racionalidad de la ciega, incluso José Luis, que aboga por educar a su prima y la defiende de los maltratos del resto, acusa a la ciega de ignorar "la verdad", imputándola: "...vives de inventos, te imaginas y te crees, la realidad no tiene para ti importancia... me da rabia que no te importe saber si es verdad o no lo que dices, ni siquiera te importa averiguar si es cierto. Lo aceptas así..., así no más..." (Serrana 137), como si la ceguera no se agotara en la no videncia, sino conllevara un modo de aprehender el mundo que esquiva la razón como principio cognoscente. Pero José Luis se debate entre diversas posibilidades de enjuiciar a la ciega, permitiendo subrepticiamente que la ceguera se convierta en signo de una diferencia entendida en términos positivos. Sin embargo, también esta divergencia debe ser pagada por la ciega, en este caso renunciando a lo que tradicionalmente se esperaría de su naturaleza femenina: "-No, tú no te casarás... tú eres distinta" (149), dictamina con convicción. Esta diferencia consiste en una atribución de habilidades especiales, que se corresponden con el modelo del ciego vidente, como lo encarna paradigmáticamente Tiresias en La Odisea, viendo lo que el resto no puede vislumbrar. José Luis le confiesa a su prima: "Cuando éramos chicos, pensaba que tú debías aprender algo,

11 "...the diagnostic category had in fact become a vehicle for imagination". La traducción es mía,

12 "Hysteria, ostensibly a point of gender demarcation, turns out to be the turning point at which the dichotomous categories constitutive of the diagnosis (feminine/masculine, body/mind, fragmentation/cohesion) can no longer hold". La traducción es mía, 
saber más, que la vida no puede ser un mirar ocioso y que posiblemente tú, que no miras, sabrías desde adentro algo que ignoraba yo" (187). Desde la visión trascendente a la que aspira José Luis, la ciega estaría más cerca de un mirar distinto, que la aproxima a la búsqueda divina que él mismo emprende. Por ello es que esta distinción no parece compatible con ser mujer, entendido en términos tradicionales. Esta diferencia, en la que José Luis cifra la ceguera de su prima, le es negada por su tío. Cuando la chica es violada, acude al argumento clásico que sitúa la culpa de la transgresión en la mujer y no en el victimario: "- ¿No ves cómo anda esa chiquilla, provocando? ¿No ven ustedes cómo se comporta? ¿O creen que porque es ciega no es como todas?" (181). Las disquisiciones, entonces, acerca de la ciega y su minusvalía se debaten entre 1) sustraerle sus capacidades cognitivas y racionales, despojándola al mismo tiempo de su estatus de sujeto; 2) adjudicarle aptitudes divergentes del resto, que la distinguen con una videncia trascendente; 3) asociar tanto sus incapacidades como sus capacidades especiales con la sustracción de su femineidad; 4) subrayar su femineidad a pesar de su ceguera. Esta última se evidencia en tanto significante móvil, que puede constituir series heterogéneas entre sí. En este sentido, la ceguera de la mujer que escribe su historia funciona para los demás personajes como otra máscara histérica, que oculta una falta de esencia estable y niega la posibilidad de ser un sujeto pleno a la protagonista. La ceguera actúa en tanto significante desplazable de una diferencia nunca saldable. José Luis, quien considera que la única gracia de su prima ciega es justamente que la no videncia la aleja del común de las mujeres, le recalca su distinción: "Subrayó la palabra distinta tantas veces que me quedé pensando en cómo ser distinta y más que nada en ser distinta de quién y que si yo era distinta de uno podía ser igual a otro..." (138). La ceguera circula a modo de casilla vacía actualizada de maneras divergentes por las diversas voces autorizadas para dar opinión en el transcurso de la novela, resultando siempre desalojada de un sentido pleno. La ceguera, en el caso de la mujer protagonista de En blanco y negro, se vincula de la misma forma que la ninfomanía de Amalia en La mujer de sal con un posicionamiento masculino que sitúa la femineidad en una línea con un exhibicionismo superficial. El ser superficie sin fondo, el ser máscara sin sustancia, el ser cifra de una diferencia cuyo contenido es siempre desplazable, puede ser reconocido asimismo en la pequeña nouvelle Cuaderno de una muchacha muda de Margarita Aguirre, publicada en Buenos Aires el año 1951.

\subsection{Las palabras estremecedoras de la mudez}

"¿Por qué no podremos ser los mismos para todos? Somos tantos que no somos nada" (Aguirre 11). El fantasma de la nada pareciera merodear por las tres obras comentadas; también la muda de Aguirre riñe con los diversos nombres que recibe por parte de los personajes que la rodean en el hospital en el cual se encuentra recluida, y que le impiden reconocerse y fundarse como sujeto. Probablemente no haya minusvalía más significativa en su potencial simbólico que la mudez: en una sociedad logocéntrica, palabra e idea son constitutivas del sujeto. La negación del habla, de la posibilidad de comunicarse y expresarse se traducen en el reclutamiento en un hospital psiquiátrico, donde la muda comparte el aislamiento social con el hermanito Juan, que no siente, ni responde, que está solo, flotando "entre tules de 
baba" (25) y con la Biruja, "siempre en una silla de grandes ruedas" (12). Las anotaciones de la muda corresponden a comentarios y glosas fragmentarios que hace en el transcurso de algunos días desde su vida en la clínica. Mientras que para la señorita Ana del hospital la muda es la "enferma de la pieza cincuenta y seis" (11), "hermanita Tacha" (11) para el hermanito Juan, es la que habla igual que el mar: "con ronquidos" (12) para su hermano y quien no infundió sino miedo a su madre.

"Estoy condenada a que nadie me oiga. $Y$ este silencio es mi medida. Es como una fosa negra, profunda. Aquí me consumo" (13). Encerrada en sí misma, la muda no puede salir de los límites que su cuerpo le impone, como si el único orificio que pudiese funcionar en tanto posibilidad de conexión con otro fuera la boca hablante. Ver pero no poder compartir lo visto, oír pero no ser capaz de responder a lo escuchado, sentir pero siempre para sí misma: esta es la condena de la muda. Este encierro en los confines de su propia corporalidad que le significa a la que escribe su mudez genera una especie de confusión y superposición de los sentidos, insinuando que es la palabra hablada, la participación en un logos compartido, la que hace posible su separación instrumental. Las voces de la muda "tienen color. Son rojas, oscuras, como la sangre muerta, como la costra de las heridas y los rasguños" (9). En otro momento siente deseo de devorar lo que la vista por sí sola no parece ser capaz de absorber con la intensidad que ella anhela: "He visto unos maravillosos dibujos en colores. Hubiera querido comerlos. Hacerlos míos para siempre. Metérmelos por los ojos adentro" (10) o "Hoy he sentido nuevamente ganas de comer flores. Bajé al jardín y corté una rosa. Estaba caliente, blanda. Su extraño sabor me produjo escalofríos" (10). La forma de aprehender el mundo que la rodea está hecha de heterogéneos materiales, cuya jerarquización no está liderada por la razón lógica. Ve con la lengua, siente con los ojos, escucha con el tacto, percibe que "las palabras se amontonan en [sus] manos y las hacen pesadas" (13). El cuerpo de la muda, que no puede comunicarse con otros porque no habla, genera un circuito propio, que establece sus particulares formas de entrar en vínculo con el mundo circundante. Lo que a manera de un hilo rojo hilvana furtivamente estas tentaculares vías que la muda traza hacia el exterior es la experiencia sinestésica ${ }^{13}$. Me parece que los diversos debates en torno a la histeria y el gran interés que tanto producciones como discursos estéticos han mostrado por ella, se superponen con la problemática de la sinestesia. La desconfianza así como el atractivo de lo que Didi-Huberman Ilama en su estudio sobre la histeria la "porosidad integral del cuerpo" (103), hacen de sinestesia e histeria puntos álgidos para poner a prueba categorías de pensamiento y sistemas

13 El término sinestesia fue usado por primera vez por el neurofisiólogo Alfred Vulpian, quien intentaba delimitar la transferencia de estímulos a nervios no específicos para su transmisión, Casi simultáneamente, la literatura de la decadencia finisecular incursionaba en las posibilidades creativas del cruce y superposición de sentidos, Recuérdese a Des Esseintes, héroe hipersensible y enfermizo de $A$ rebours (1884) de Huysmans -la así llamada biblia de la decadencia- quien, a través de experimentos sinestésicos, busca excitar sus agotados nervios, En la misma década el crítico cultural Max Nordau acusaba la sinestesia como patológica, pues contradiría el equilibrio nervioso y la supuesta intencionalidad de la naturaleza, Lo que quisiera rescatar en esta comparecencia sintética de la sinestesia en discursos médicos, pseudocientíficos y estéticos de la segunda mitad del siglo XIX es que se vuelve núcleo problemático en discursos en torno a la razón moderna, 
clasificatorios que atañen tanto la dicotomía de salud y enfermedad como la de masculinidad y femineidad. La histérica, como la "sinestésica", podríamos agregar, está en constante peligro de dar un paso en falso en la posesión de su cuerpo. El cuerpo se vuelve algo tan propio, con tanto potencial de actuar por su cuenta, que amenaza con convertirse en algo ajeno, capaz de escapar al control. "... este riesgo es una vacilación sin fin y una tentativa recurrente de poner término a la vacilación, un cuestionar sin tregua de la desgracia: ¿dónde, dónde colocar ese cuerpo?" (Didi-Huberman 149). Este mismo rebasamiento, este resto que queda sin administración es lo que hizo tan atractivo a la histeria para los surrealistas, quienes convierten a la emblemática Augustine de la Salpêtrière en su heroína ${ }^{14}$. La histeria así como la sinestesia obligan a pensar con la paradoja, quizás incluso a favor de ella, haciéndola comparecer en tanto experiencia sintomática que vehicula un malestar frente a un mundo regido por una razón normativa y homogenizante.

Pareciera que en cierta medida el texto de Aguirre funciona de manera inversa a las novelas de Gertner y Serrana, en el sentido de que podríamos leer la condena a la reclusión por la mudez de su protagonista como la respuesta que el sistema patriarcal da a su diferencia. El aislamiento en el hospital trae consigo el encierro de la muda en sí misma: su incapacidad de hablar se convierte en una imposibilidad de participar de la palabra y del logos, por lo tanto de convivir en tanto sujeto íntegro con otros. Un cuerpo histérico es obligado a su mudez. Pero muestra signos de resistencia, buscando salidas en aperturas e interconexiones a través de las experiencias sinestésicas. La sinestesia es una forma de histerizar el cuerpo, volverlo penetrable, comunicable, abierto, negando así la clausura a la que la cultura occidental patriarcal lo ha condenado. El filósofo Jean-Luc Nancy aboga por un cuerpo poroso, en tanto única posibilidad de escabullir la censura que ha padecido el cuerpo en las formas occidentales de pensar y representarlo. Escribe Nancy:

El cuerpo va por espasmos, contracciones y distensiones, pliegues, despliegues, anudamientos y desenlaces, torsiones, sobresaltos, hipos, descargas eléctricas, distensiones, contracciones, estremecimientos, sacudidas, temblores, horripilaciones, erecciones, náuseas, convulsiones. Cuerpo que se eleva, se abisma, se abre, se agrieta y se agujerea, se dispersa, se echa, se salpica y se pudre o sangra, moja y seca o supura, gruñe, gime, agoniza, cruje y suspira (31-32).

14 En 1928, los surrealistas conmemoran el quincuagésimo cumpleaños de Augustine con reproducciones de algunas de las fotografías de las fases extáticas de la más célebre y emblemática de las histéricas, Los vanguardistas celebran a la histeria como el gran descubrimiento poético del siglo XIX, convirtiendo a Augustine y su padecimiento en una obra de arte. Escriben Louis Aragon y André Breton en su manifiesto: "Nosotros, surrealistas, queremos celebrar aquí el cincuentenario de la histeria, el mayor descubrimiento poético de finales del siglo XIX, y esto en el momento mismo en que el desmembramiento del concepto de histeria parece un hecho consumado. Nosotros, que nada amamos tanto como a esas jóvenes histéricas, cuyo tipo perfecto nos lo facilitó la observación relativa a la deliciosa $X, L_{1}$ (Augustine) ingresada en la Salpêtrière en el Servicio del doctor Charcot el 21 de octubre de 1875 a la edad de quince años y medio, estamos muy afectados por la laboriosa refutación de los trastornos orgánicos, cuyo proceso no será el de la histeria más que a ojos de los simples médicos" (101-2). 
El texto de Nancy podría estar acompañando las fotografías que Albert Londe tomara en la Salpêtrière de las mujeres atendidas por Charcot, nombrando las diversas fases de un paradigmático ataque histérico. Para Nancy, entonces, la única forma de superar los modos en que Occidente ha reflexionado sobre el cuerpo, es, de alguna manera, histerizándolo, volviéndolo vulnerable, abierto, expuesto, transgresor de sus límites y confines. La clásica dicotomía entre mente y cuerpo, muy emparentada con y solidaria de las oposiciones entre salud y enfermedad, así como de masculinidad y femineidad solo es salvable volcando el cuerpo hacia la carne. Dice Nancy: "Cuerpo oxímoron polimorfo: adentro/afuera, materia/forma, homo/heterología, auto/alonomía, crecimiento/excrecencia, mío/nada..." (33).

¿No es justamente el cuerpo de la muda de Aguirre una paradoja que se soslaya de sus contradicciones, haciendo de ellas su más grande fortaleza? Cuerpo abierto, que come con los ojos, que siente con la boca, que habla con palabras que no parecen pertenecer al orden logo y fonocéntrico de la cultura dominante, la muda de Aguirre busca su histerización para escapar a la negación a la que su cuerpo divergente ha sido condenado. El mundo circundante quiere acallar un cuerpo incómodo, que lucha por su supervivencia. Histeria buscada y deseada en tanto forma de hacerse visible y audible para un mundo que se pretende y quiere ciego y sordo frente a la diferencia. La muchacha muda de Aguirre habla con y a través del texto histérico de su cuerpo, como única forma de superar el silencio al que ha sido confinado.

\section{Reflexiones finales o la escritura que se niega a callar}

Resulta sintomático que las tres obras comentadas con anterioridad adopten la primera persona autobiográfica como perspectiva de escritura. La mise en abyme de la puesta en escena del acto escritural en tanto intento de constitución de un sujeto autorial se conformará como contra o sobreescritura de la condena histérica. Las narradoras de los tres textos escriben para escribirse, para escabullir las etiquetas patológicas de lo femenino vehiculizadas por los discursos masculinistas. La femineidad vista desde la patología transfiere la lógica de la enfermedad a la lógica del género femenino, volviéndose la enfermedad -la histeria- cifra de lo femenino. Jugando con esta superposición que niega, finalmente, sea por hiperbolización y/o minimización, a la mujer, el acto escritural-autorial se evidencia como forma de protesta, aunque sea desde el ámbito de la ficción, frente a esta borradura.

Amalia, de La mujer de sal, escribe, como ella misma expresa en su texto, para buscar "[I]a verdad" (Gertner 47), la explicación de sí misma, una que no se agote en la descripción de los síntomas de la ninfomanía o histeria. Escribe para superar el poder performativo de la palabra ninfómana, aquel que la reduce a ser pura sintomatología, mero cuerpo, solo sexualidad: mujer. El acto escritural de Amalia pretende contradecir el diagnóstico de Théo: la historia de La mujer de sal, que es la historia de Amalia y es la narración que la propia Amalia realiza -en una construcción de círculos concéntricos, en la cual un relato contiene al otro- es la historia de una contestación, aquella que se dirige contra lo que Théo implica al tratarla de ninfómana: es un escribir de la mujer contra la nada, una escritura de inscripción en el ser. Amalia escribe buscando conquistar el estatus de sujeto que Théo le niega, 
al agotarla en el término de la ninfomanía. Lo que la mujer de sal hace con su acto escritural es evocar su "mandato simbólico", es reclamar su "lugar dentro de la red socio-simbólica" (Žižek 216).

"Salía el sol cuando entraba Lot en Segor e hizo Yavé llover azufre y fuego de Yavé desde el cielo... Sara, la mujer de Lot, miró hacia atrás y se convirtió en un bloque de sal" (Gertner 14-15). La historia bíblica suele interpretarse como un castigo de Dios a la curiosidad de la mujer, que es incapaz de someterse al mandato divino que prohíbe, al salir de la ciudad de Sodoma en aras de su salvación, mirar hacia atrás. Amalia, al generar un lazo intertextual entre su diario de vida y este episodio del antiguo testamento, no solo contradice el diagnóstico de Théo acerca de sí misma, sino también realiza una sobreescritura de la curiosidad femenina de Sara. Tal como Amalia no es ninfómana, el problema de Sara no es su curiosidad, otro significante vacío que entraría en serie con la femineidad: lo que ambas mujeres son incapaces de hacer, lo que en definitiva marca su enfermedad y las lleva a la muerte, es un trabajo de duelo efectivo. Son, en términos freudianos, mujeres melancólicas. Leída desde su propia perspectiva, la historia de Amalia urde la trama de una mujer impedida de olvidar a su gran amor, un hombre casado que nunca pudo asumir más que el papel de amante frente a ella. Lo que busca Amalia en los brazos de otros hombres, lo que su cuerpo anhela al pegarse a otros, es la reminiscencia de aquel cuerpo amado perdido. Entrampada en esta estructura melancólica, termina suicidándose.

No es casual que la elección de María Elena Gertner haya recaído sobre estos cuadros patológicos, puestos en juego en la novela: tachada de ninfómana, es decir, de histérica, la mujer se agotaría en la sexualidad, en la máscara. Sin embargo, la protagonista resulta ser melancólica y suicida. Una histérica no se suicida, amenaza con hacerlo, mientras que Amalia se quita la vida, sin dar aviso ni echar pie atrás ${ }^{15}$. Por otro lado, la melancolía es, desde sus orígenes en la patología humoral griega, una enfermedad predominantemente masculina, asociada al pensamiento y la reflexión.

Žižek cruza a Weininger con Lacan, cuya célebre aseveración "la mujer no existe" recuerda a la negación de existencia y esencia realizada por Weininger, citada más arriba. Sin embargo, lo que prima en Lacan es el convencimiento de que el "hecho ontológico primordial es el vacío" (Žižek 217). En palabras de Žižek: "Toda identidad simbólica que adquiero es, en última instancia, nada más que un rasgo suplementario cuya función es llenar este vacío" (217). Y sería este miedo al vacío ontológico el que para el hombre es encarnado por la mujer. La ninfomanía de Amalia así como la curiosidad de Sara, leídos desde esta perspectiva, se devuelven a Théo y a Dios en forma de su propio miedo frente a la nada. Invisten a las mujeres de aquella nada, reduciéndolas a ser solo máscara, mera mujer, escapando al terror del vacío.

15 Žižek escribe acerca del "teatro histérico: "... el sujeto es atrapado en una mascarada en la cual lo que parece mortalmente serio se revela como un fraude, y lo que parece ser un gesto vacío, se revela como mortalmente serio" (227), 
Este mismo juego con la nada, en que se convierten las diversas adjudicaciones identitarias que recibe la ciega de En blanco y negro de Serrana, es el que produce la escritura de la protagonista: "Comencé a desear con toda mi alma ver claro y no seguir agarrada a mixtificaciones que me bastaron como una religión" (Serrana 266) y " $¿$ [q]ué futuro tienen las mujeres solas? El futuro del verbo desconocido; el futuro mío, vano. Y comencé por primera vez a preguntarme yo también: ¿Qué futuro tienen las mujeres ciegas? ¿Cómo se hace un futuro? El futuro del verbo ser. ¿Qué seré? ¿Qué será de mí?" (267). Mujer sola, mujer ciega, mujer histérica. Escritura contra la soledad, la ceguera, la histeria. Una escritura que aventure posibles respuestas frente a la pregunta del destino, de cómo y qué ser, interrogantes siempre respondidas por las voces masculinas, respuestas que la escritura intenta contestar, ahora desde una visión propia. Sin embargo, y siguiendo los planteamientos de Gilbert y Gubar, esta visión propia, es decir, articulada con propiedad -poseyéndola-, se le hace imposible al género femenino, que ha sido definido y representado con reiteración por la autoría y autoridad masculina (xii). La metáfora de la paternidad literaria, que implica la posesión de los textos como si de hijos hechos a la propia semejanza se tratara, y a su vez, un paralelismo entre falo y pluma -señalando simultáneamente para el hombre la posición de ser quien imprime el vacío y la falta en la mujer- es la que pesa sobre la mujer que decide ingresar a la escritura. Esta "esquizofrenia de la autoría" (Gilbert y Gubar 69) es constitutiva para la genealogía de la escritura de mujeres, que no puede escapar a las formas en las que cultura patriarcal y autoría masculina la ha imaginado y representado. Casi obsesivamente las escritoras mujeres vuelven, como el asesino al lugar de su crimen, a los tópicos y la topografía que la tradición hecha por hombres ha fijado para ellas.

Amalia escribe su historia y se la lega a Théo, testigo de su existencia, constante interlocutor y receptor de su autobiografía. Precisamente en este acto reside la paradoja de la escritura de mujeres, que intenta liberarse de las prescripciones masculinas, pero busca, irremediablemente, el reconocimiento de una autoridad masculina. La ciega dirige su escritura reivindicadora a su primo José Luis, terminando la novela con la siguiente afirmación: "En algunos aspectos me hace falta tu consejo. Hay cosas que yo no puedo hacer. Recuerda que soy ciega..." (295). Evidencia de una imposibilidad de escabullir, una vez y para siempre, las historias e histerias en las que ha sido urdido lo femenino.

La muda de Aguirre intercala las anotaciones de su diario íntimo con cartas que dirige al hermanito Juan, sabiendo que quizás nunca las reciba ni menos lea: "No sé por qué te digo esto. Tal vez porque necesitaba escribirte" (Aguirre 19). Estos actos fallidos, de escribir a quien por otro lado se intenta sobreescribir, contienen los núcleos problemáticos de una escritura de mujeres que no cuenta con una tradición a la cual apelar y la cual integrar. Una escritura que no puede dejar de reflexionar sobre sus posibilidades y limitaciones, que no deja de exhibir, en forma paradójica, aquello que desea tachar. 


\section{Obras citadas}

Aguirre, Margarita. Cuaderno de una muchacha muda. Buenos Aires: Ediciones Botella al Mar. 1951.

Aragon, Louis y Breton, André. "El cincuentenario de la histeria (1878-1928". Revista de la Asociación Española de Neuropsiquiatría. [online]. 2007, vol.27, n.1, 101-102.

Beizer, Janet. Ventriloquized Bodies. Narratives of Hysteria in NinteenthCentury France. Ithaca and London: Cornell University Press. 1994.

Brooks, Peter. Body Work. Objects of Desire in Modern Narrative. Cambridge, Massachusetts/London, England: Harvard University Press. 1993.

Carreño Bolívar, Rubí. Leche amarga: violencia y erotismo en la narrativa chilena del siglo XX (Bombal, Brunet, Donoso, Eltit). Santiago de Chile: Editorial Cuarto Propio. 2007.

Didi-Huberman, Georges. La invención de la histeria. Charcot y la iconografía fotográfica de la Salpêtrière. Trad. de Tania Arias y Rafael Jackson. Madrid: Cátedra, 2007 [1982].

Doll, Darcie. "Desde los salones a la sala de conferencias: mujeres escritoras en el proceso de constitución del campo literario en Chile", en Revista Chilena de Literatura 71, 83-100. 2007.

Foucault, Michel. Historia de la sexualidad. 1. La voluntad de saber. Trad. de Ulises Guiñazú. México: Siglo XXI, 2009 [1976].

Gilbert, Sandra M. \& Susan Gubar, The Madwoman in the Attic. The Women Writer and the Ninteenth-Century Literary Imagination. New Haven and London: Yale University Press, 200 [1979].

Godoy Gallardo, Eduardo. La generación del 50 en Chile. Historia de un movimiento literario (narrativa). Santiago de Chile: Editorial La Noria, 1992 [1991].

Kottow, Andrea. "Feminismo y femineidad: escritura y género en las primeras escritoras feministas en Chile". Aceptado para su publicación en Atenea.

Lafourcade, Enrique. Antología del nuevo cuento chileno. Santiago: Zig-Zag, 1954.

Lamperein, Lina Vera. Presencia femenina en la literatura nacional. Una trayectoria apasionante. 1750-1991. Santiago de Chile: Editorial Cuarto Propio. 1994.

Melville Logan, Peter. Nerves \& Narratives. A Cultural History of Hysteria in 19th-Century British Prose. Berkeley and Los Angeles, California: University of California Press, 1997.

Nancy, Jean-Luc. 58 indicios sobre el cuerpo. Extensión del alma. Trad. Daniel Alvaro. Buenos Aires: La Cebra, 2011.

Olea, Raquel. "Escritoras de la generación del cincuenta. Claves para una lectura política". Universum. N 25, Vol. 2 (2010). 101-116.

Traverso, Ana. "Primeras escritoras en Chile y autorización del oficio literario". Anales de Literatura Chilena, Año 13, Junio 2012, Número 17. 61-80.

Vicuña, Manuel. La Belle époque chilena. Alta sociedad y mujeres de élite, 2. edición, Santiago de Chile: Catalonia. 2010.

Weininger, Otto. Geschlecht und Charakter. Eine prinzipielle Untersuchung. Wien/Leizpig: Wilhelm Braumüller, 1903.

Žižek, Slavoj. Las metástasis del goce. Seis ensayos sobre la mujer y la causalidad. Trad. Patricia Willson. Buenos Aires: Paidós, 2003. 